Ключевые слова: идентификация личности, дерматоглифика.

\title{
PROSPECTS OF USING COMPUTER TECHNOLOGY IN DERMATOGLYPHICS INVESTIGATIONS
}

\author{
N.M. Kozan, Yu.Z. Kotsiubyns'ka
}

Abstract. Possibilities and trends of using advanced computer technologies in the identification of an unknown person have been dealt with in the paper. A classification of modern electronic devices for a dermatoglific research in the practice of a forensic medical examination and prospects of their using has been submitted.

Key words: personal identification, dermatoglyphics.

National Medical University (Ivano-Frankivsk)

Рецензент - проф. В.Т. Бачинський

Buk. Med. Herald. - 2013. - Vol. 17, № 3 (67), part 1. - P. 82-83

Надійшла до редакції 04.06.2013 року

(C) Ю.З. Коцюбинська, Н.М. Козань, 2013

УДК 340.6:616-076:577.21

Р.Г. Кривда, І.В. Ланцман

\section{ДОСЛІДЖЕННЯ ГЕНОМНОЇ ДНК, ВИДІЛЕНОЇ ІЗ ГІСТОЛОГІЧНИХ ПРЕПАРАТІВ, ДЛЯ ПРОВЕДЕННЯ СУДОВО-МЕДИЧНИХ МОЛЕКУЛЯРНО-ГЕНЕТИЧНИХ ЕКСПЕРТИЗ}

Одеський національний медичний університет

Резюме. У роботі показана можливість використання гістологічних препаратів, як біологічні зразки, при проведенні судово-медичних молекулярногенетичних експертиз із метою ідентифікації особи та

Вступ. Основними завданнями судовомедичної молекулярно-генетичної експертизи $є$ ідентифікація особи та встановлення біологічної спорідненості.

Принцип проведення судово-медичної молекулярно-генетичної експертизи полягає в порівняльному аналізі профілів геномної ДНК, виділеної з будь-яких біологічних тканин. У судовомедичній практиці часто виникають експертні задачі, вирішення яких можливе лише за рахунок дослідження гістологічного матеріалу від живих або померлих осіб. Наприклад, у випадках необхідності встановлення належності гістологічних біопсійних препаратів конкретній особі, або за необхідності встановлення біологічної спорідненості, якщо передбачуваний батько (мати) померли і єдиним придатним для проведення судовомедичного молекулярно-генетичного експертного дослідження біологічним матеріалом можуть бути гістологічні препарати [1].

Дослідження складається з наступних етапів: виділення геномної ДНК з біологічного матеріалу, ампліфікація та подальший аналіз гіперваріабельних ділянок ДНК, специфічних для кожного індивідуума. встановлення біологічної спорідненості (батьківства, материнства).

Ключові слова: геномна ДНК, гістологічні препарати, ПЛР, ідентифікація особи, біологічна спорідненість.

Висока чутливість полімеразної ланцюгової реакції висуває певні вимоги щодо правил відбору об'єктів і екстракції ДНК з «архівного» біологічного матеріалу - гістологічних препаратів. Необхідно індивідуально добирати відповідну методику дослідження залежно від виду гістологічного об'єкта та його стану $[2,3]$.

Мета дослідження. Визначити можливості використання гістологічних препаратів тканин, відібраних під час біопсій, а також препаратів біологічних тканин, що відбиралися при патолого-анатомічних дослідженнях трупів, як біологічні зразки, при проведенні судово-медичних молекулярно-генетичних експертиз із метою ідентифікації особи та встановлення біологічної спорідненості (батьківства, материнства).

Матеріал і методи. Як об'єкти для експериментального дослідження протестовано чотири групи випадково відібраних гістологічних препаратів, які позначали відповідно I, II, III, IV. До I групи входили біологічні тканини пухлинного походження в парафінових блоках, відібрані під час біопсій $(\mathrm{n}=42)$, до II групи - біологічні тканини пухлинного походження на предметних скельцях, відібрані під час біопсій $(\mathrm{n}=42)$, III групу

(ㄱ) Р.Г. Кривда, І.В. Ланцман, 2013 
складали біологічні тканини у вигляді «вологого» архіву автопсійного матеріалу (n=60), IV група складалася 3 біологічних тканин автопсійного матеріалу в парафінових блоках $(\mathrm{n}=29)$. При дослідженні була відсутня інформація щодо виду тканини, часу з моменту проведення біопсій та автопсій, часу фіксації тканин у формаліні та його концентрації.

Геномну ДНК виділяли із 10-15 мг біологічної тканини гістологічних препаратів за допомогою набору реагентів «PrepFiler® BTA Forensic DNA Extraction Kit» (Applied Biosystems", СШA).

Виділену ДНК фракціонували методом горизонтального «підводного» електрофорезу в електрофорезній камері «Hoefer Scientific Instruments» (США). Електрофорез здійснювали протягом 1 години при напрузі постійного струму 70 В у 1хTВE буфері (50 мМ трис- $\mathrm{H}_{3} \mathrm{BO}_{3}, 2$ мМ $\mathrm{Na}_{3}$ ЕДТА, $\left.\mathrm{pH} 8,0\right)$ в $1 \%$ агарозному гелі $з$ додаванням бромистого етидію до кінцевої концентрації 0,5 мкг/мл.

Концентрацію виділеної геномної ДНК вимірювали за допомогою флуориметра Qubit ${ }^{2} 2.0$ (Invitrogen/Life Technologies, США) 3 використанням набору реагентів Qubit ${ }^{\circledR}$ dsDNA BR для кількісного визначення дволанцюгової ДНК.

ДНК, виділену із біологічної тканини гістологічних препаратів, досліджували за допомогою н а бору для П Л Р - ампл і фіка ц ї̈ "AmpFlSTR®Identifiler Plus" (Applied Biosystems", США), з терміном придатності не менш ніж дев'ять місяців, відповідно до інструкції, яка додається виробниками реагентів. При постановці ПЛР здійснювали негативний і позитивний контроль. Дослідження проводили з використанням системи «GeneAmp ${ }^{\circledR}$ PCR 2720» ("Applied Biosystems", США). Розділення продуктів ампліфікації проводили з використанням пристрою 3130 Genetic Analyzer ("Applied Biosystems", США). Аналіз продуктів ампліфіка- ції з встановленням алелів проводили за допомогою програми «Gene Mapper ID Software Version $3.1 »$.

Результати дослідження та їх обговорення. У цілому, при визначенні кількості ДНК, виділеної з I групи біологічних тканин, спостерігалися достатньо високі показники концентрації екстрагованої ДНК (у середньому 21,0 нг/мкл), для II і IV груп гістологічних препаратів спостерігалося зменшення концентрацій виділеної ДНК, у середньому, до 1,5 нг/мкл та 1,2 нг/мкл відповідно. В умовах проведеного дослідження для III групи об'єктів виявилося можливим виділити ДНК у середній концентрації 2,3 нг/мкл. Дані про кількість ДНК, виділеної з об'єктів дослідження, наведені в табл. 1.

Результати електрофоретичного розподілу в 1 \% агарозному гелі ДНК, виділеної з об’єктів груп I і II показали, що ДНК, виділена з усіх досліджуваних об'єктів, характеризується як деградована (з довжиною фрагментів від 9000,0 до 200,0 п. н.) зі збереженням фракції високомолекулярних фрагментів, що дає змогу в подальшому успішно ампліфікувати зазначену ДНК. У той же час для групи III виділена ДНК має виражені ознаки високого ступеня деградації (з довжиною фрагментів до 100,0 п. н.), що свідчить про іiї непридатність для проведення ПЛР. Довжина фрагментів виділеної ДНК об'єктів IV групи складала до 250,0 п. н.

Для оцінки придатності виділеної з об'єктів ДНК проводили ії ПЛР-типування за допомогою н а б о р у д л я П Л Р - а м п л і ф ік а ц і ї "AmpFlSTR®Identifiler Plus" (Applied Biosystems", США). Результати типування наведено в табл. 2.

У результаті типування виділеної ДНК біологічних тканин I групи стійкі та відтворювані профілі ДНК одержані для 40 об'єктів з 42, що становило 95,0 \% успішного генотипування екстрагованої ДНК. Для II групи профілі ДНК були одержані у 37 випадках 3 42, що становило

Таблиця 1

Кількість ДНК, виділеної із об'єктів дослідження, нг/мкл

\begin{tabular}{|c|c|c|c|}
\hline $\begin{array}{c}\text { Групи об’єктів } \\
\text { дослідження }\end{array}$ & Середнє значення, М & Мінімальне значення & Максимальне значення \\
\hline I (n=42) & 21,0 & 8,8 & 43,0 \\
\hline II (n=42) & 1,3 & 0,83 & 4,0 \\
\hline III $(\mathrm{n}=60)$ & 2,3 & 2,9 & 5,8 \\
\hline IV $(n=29)$ & 1,2 & 2,1 & 3,9 \\
\hline
\end{tabular}

Таблиця 2

Кількість та відсоток ДНК-профілів, одержаних при дослідженні біологічних тканин об'єктів I, II, III та IV груп

\begin{tabular}{|c|c|c|}
\hline Групи об'єктів дослідження & Кількість, $\mathrm{n}$ & Відсоток, \% \\
\hline $\mathrm{I}(\mathrm{n}=42)$ & 40 & 95,0 \\
\hline $\mathrm{II}(\mathrm{n}=42)$ & 37 & 88,0 \\
\hline $\mathrm{III}(\mathrm{n}=60)$ & - & - \\
\hline $\mathrm{IV}(\mathrm{n}=29)$ & 2 & 7,0 \\
\hline
\end{tabular}


88,0 \%, для IV групи ампліфіковано два профілі 3 29 , що відповідає 7,0 \% позитивного типування. Слід зазначити, що для III групи об'єктів, в умовах даного експерименту із застосуванням наявного обладнання та реагентів, одержати продукти ампліфікації виділеної ДНК не виявилося можливим, що підтверджується результатами електрофорезу в агарозному гелі та проведенням кількісної оцінки екстрагованої ДНК.

У першу чергу, це пов'язано з високим ступенем деградації молекул ДНК об'єктів III групи, яка виражається у вигляді окиснення, дезамінування і депуринізації, розривами як однієї, так і двох ланцюгів дуплексу ДНК, пов’язаною з дією формаліну при тривалій експозиції.

\section{Висновок}

Таким чином, результати даного дослідження показали, що найбільш придатними для проведення судово-медичної молекулярно-генетичної експертизи, як зразки $з$ метою ідентифікації особи та встановлення біологічної спорідненості, виявилися біологічні тканини пухлинного похо- дження, відібрані під час біопсій у вигляді парафінових блоків та на предметних скельцях.

Перспективи подальших досліджень. Актуальним $\epsilon$ подальше молекулярно-генетичне дослідження гістологічних препаратів з урахуванням впливу різних методів фіксації біологічних тканин на стан та якість ДНК.

\section{Література}

1. Орлова О.А. Використання гістологічних препаратів при проведенні судово-медичних молекулярногенетичних експертиз із метою ідентифікації особи і встановлення біологічного батьківства (материнства) / О.А. Орлова, І.В. Ланцман // Сучасні теоретичні та практичні аспекти клінічної медицини: науковопрактична конференція з міжнародною участю, 19-20 квіт. 2012 р., Одеса: тези доп. - Одеса, 2012. - С. 34.

2. Pilot study of DNA extraction from archival unstained bone marrow slides comparison of three rapid methods / M.A. Gari, A.M. Abuzenadah, A.G. Chaudhary [et al.] // African J. of Biotechnology. - 2006. - Vol. 5, № 6. P. 532-535.

3. Extraction of genomic DNA from formalin fixed tissues of different wild avian species / K. Shrivastava, M.S. Thakur, M.P.S. Tomar [et al.] // Annals of Biological Research. - 2012. - Vol. 3, № 7. - P. 3174-3175.

\section{ИССЛЕДОВАНИЕ ГЕНОМНОЙ ДНК, ВЫДЕЛЕННОЙ ИЗ ГИСТОЛОГИЧЕСКИХ ПРЕПАРАТОВ, ДЛЯ ПРОВЕДЕНИЯ СУДЕБНО-МЕДИЦИНСКИХ МОЛЕКУЛЯРНО-ГЕНЕТИЧЕСКИХ ЭКСПЕРТИЗ}

\section{Р.Г. Кривда, И.В. Ланцман}

Резюме. В работе показана возможность использования гистологических препаратов в качестве биологических образцов при проведении судебно-медицинских молекулярно-генетических экспертиз с целью идентификации личности и установления биологического родства (отцовства, материнства).

Ключевые слова: геномная ДНК, гистологические препараты, ПЦР, идентификация личности, биологическое родство.

\section{INVESTIGATION OF GENOMIC DNA, EXTRACTED FROM HISTOLOGICAL PREPARATIONS, FOR CONDUCTING FORENSIC-MEDICAL MOLECULAR-GENETIC EXAMINATIONS}

\section{R.H. Kryvda, I. V. Lantsman}

Abstract. In this paper we have demonstrate a possibility of the application of histologic specimens as biological samples in the process of performing forensic medical molecular-genetic examinations of the personality identification and establishing the biological relationship (paternity, maternity).

Key words: genomic DNA, histological preparations, PCR, personality identification, biological relationship.

National Medical University (Odesa)

Рецензент - проф. В.Т. Бачинський

Buk. Med. Herald. - 2013. - Vol. 17, № 3 (67), part 1. - P. 83-85

Надійшла до редакції 07.06.2013 року

(ㄱ Р.Г. Кривда, І.В. Ланцман, 2013 